\title{
New Developments in Diagnosis and Treatment of Heparin- induced Thrombocytopenia
}

\author{
Norbert Lubenow \\ Institut für Immunologie und Transfusionsmedizin, Ernst-Moritz-Arndt-Universität Greifswald, Germany
}

Key Words

Thrombocytopenia . Heparin . Thrombosis

\begin{abstract}
Heparin-induced thrombocytopenia (HIT) is a drug induced immune mediated thrombocytopenia that affects up to $3 \%$ of patients treated with unfractionated heparin (UFH). It is less frequent when low molecular weight heparins (LMWH) are used. Fondaparinux does not seem to induce HIT. A functional and an antigen assay should be performed to confirm the clinical diagnosis of HIT. Immediate cessation of heparin and start of compatible anticoagulant is mandatory when HIT is suspected clinically. Danaparoid (a heparinoid) and the direct thrombin inhibitors lepirudin and argatroban are available for this purpose. Short-term reexposure with heparin, for example during cardiopulmonary bypass, is possible in patients with history of HIT, provided HIT antiodies are no longer detectable. In children systematic data on treatment of HIT are lacking.
\end{abstract}

Copyright $@ 2004$ S. Karger AG, Basel

\section{KARGER}

Fax +4161306 1234 E-Mail: karger@karger.ch www.karger.com (c) 2004 S. Karger AG, Basel 1424-8832/04/0336-0407\$21.0/0

Accessible online at: www.krager.com/pht

\section{Introduction}

Heparin-induced thrombocytopenia (HIT) is the most important and most frequent drug-induced, immune-mediated thrombocytopenia.

In HIT platelet counts usually decrease by $>50 \%$ of the highest preceeding value [1] or below 100,000 Gpt/L after day 5 of heparin treatment. In case of reexposure within 100 days this drop can occur earlier [2]. Thrombocytopenia of $<20,000 \mu \mathrm{l}$ occurs in less than $10 \%$ of HIT-patients [3]. Typical thromboembolic complications (TECs) associated with HIT are deep venous thrombosis, pulmonary embolism [4], venous limb gangrene [5], cerebral vein thrombosis [6], arterial thrombosis [3]. Heparin-induced skin lesions [7] and acute systemic reactions can also occur. Bleeding complications may occur in patients with concomitant uremic thrombocytopathy but are not typical for HIT.

Studies screening symptomatic as well as asymptomatic patients [8-13] showed that most patients who form HIT antibodies do not develop clinical HIT. Clinically significant HIT, however, occurs in up to $3 \%$ of patients treated with unfractionated heparin [8,14]. Different patient populations can have greatly differing incidences of clinically inapparent HIT antibodies as well as clinically manifest HIT.
Norbert Lubenow

Ernst-Moritz-Arndt Universität

Institut für Immunologie und Transfusionsmedizin

Klinikum/Sauerbruchstrasse

17489 Greifswald, Germany

Tel: +49 3834 865458; Fax +49 3834 865489; E-mail: lubenow@uni-greifswald.de 


\section{Pathogenesis}

Platelet factor 4 (PF4) is the most important protein involved in the immune response of HIT [15]. After binding of heparin to PF4 a cryptantigen or autoantigen is exposed $[16,17]$. Larger and higher sulfated heparins are more able to expose this cryptantigen than low molecular weight heparin [18].

In symptomatic HIT patients, the antibodies involved are of the IgG class in $>80 \%$ of patients. Antibodies of the IgG1 class were found to be predominant among HIT-IgG [19]. But patients with HIT antibodies of the IgM or IgA class only have also been described [20].
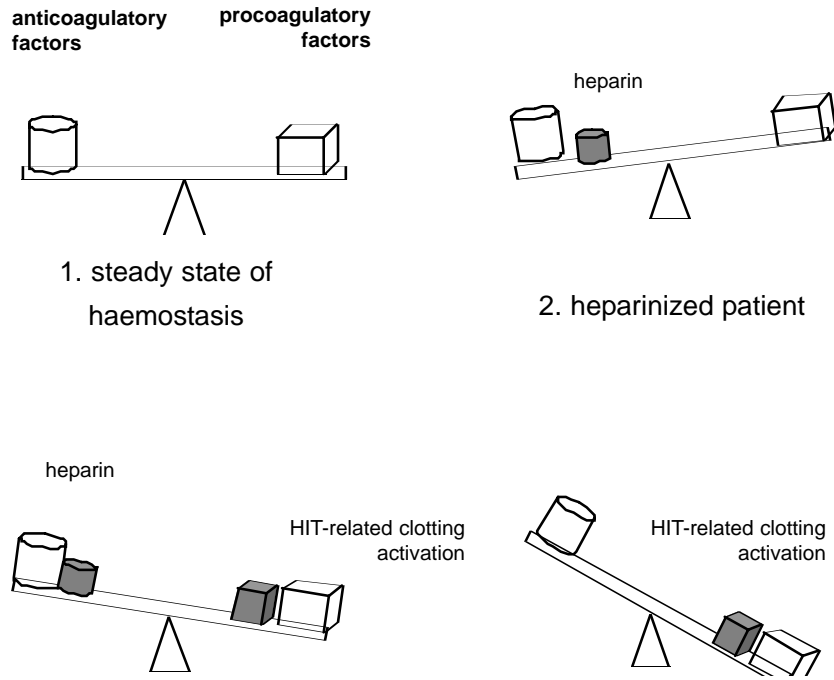

3. HIT-patient (still on heparin)

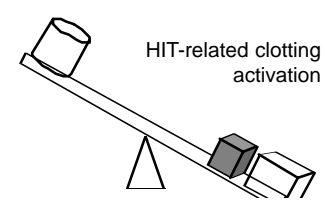

4. HIT-patient (heparin stopped)

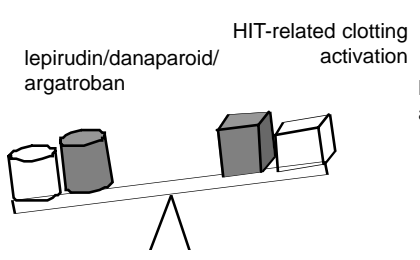

5. acute HIT-patient (heparin stopped on compatible anticoagulant)
The most important glycoprotein of the platelet membrane involved in HIT is the platelet FcyIIa receptor [21]. Binding of HIT antibodies to the PF4-heparin complexes results in large multimolecular immune complexes [15]. These complexes crosslink the FcyRIIa and cause platelet activation [22].

Thrombin plays a central role in HIT - thrombin generation is enhanced in HIT $[5,23]$ by concomitant activation of platelets [24], generation of platelet microparticles [25], and alteration of endothelial cells [26]. Activated endothelial cells upregulate tissue factor expression. Platelet microparticles and anti- PF4/heparin antibodies also cause expression of tissue factor on monocytes [27].

\section{Laboratory Testing}

In vitro demonstration of HIT-antibodies by functional (i.e. activation) and immunological assays [28] can help to confirm the clinical diagnosis of HIT.

The serotonin release assay (SRA), regarded as the gold standard, is, however, technically cumbersome and requires platelet labeling with radioactive compounds. The heparininduced platelet activation (HIPA) assay - while still technically demanding - is better suited for routine testing [28]. Results of other platelet activation dependent assays measuring e.g. luminescence, platelet derived microparticle generation, or annexin $\mathrm{V}$ expression do not differ largely as long as washed platelets are used. However, sensitivity is reduced, if performed with platelet-rich plasma.

Antigen assays use surface-bound target antigen (PF4/heparin- or PF4/polyvinylsulphate-complexes respectively) to detect the antibodies. A new gel-column system utilising this test principle has recently been introduced and evaluated, showing its suitability for HIT-antibody testing [29].

Regardless which assay is used it is important to incorporate clinical information in the interpretation of test results and to combine a sensitive functional assay with an antigen assay. Antigen assays may have greater sensitivity for HIT antibody seroconversion. Thus the functional assays' positive predictive value for clinical HIT might be greater. False negative results are estimated to be less than $5 \%$ if both test systems are applied.

\section{Therapy}

When HIT develops, immediate cessation of heparin is mandatory, but this will not stop continuing thrombin generation, nor avoid subsequent thrombotic events, which occur in as many as $40-50 \%$ of patients over the next several days or weeks [4,30]. Wallis et al. [30] showed that heparin cessation alone is not an appropriate treatment for 
HIT, and that even in HIT, heparin's anti-IIa-activity may have a beneficial impact (figure 1).

Non-heparin anticoagulants that do not cross-react with HIT antibodies, such as hirudin, argatroban or danaparoid are approved for alternative anticoagulation in HIT. Notably, hirudin and argatroban, but not danaparoid, have antithrombin activity even inside clots.

There is emerging evidence that LMWH cause HIT less often when compared to UFH [8,31], they must not however be used in patients with acute HIT.

\section{Treatment of HIT}

With respect to treatment it is important to differentiate patients groups depending on the clinical presentation [32]:

- Isolated seroconversion: presence of HIT-antibodies without clinical signs such as thrombocytopenia or thrombosis, does not mandate special treatment, nor discontinuation of heparin.

- HIT without thrombosis ("isolated thrombocytopenia"): about $50 \%$ of patients with HIT do not have a new HIT-associated thrombosis at the time HIT is first clinically suspected on the basis of thrombocytopenia alone. In a retrospective cohort study of 62 such patients with "isolated thrombocytopenia" the subsequent cumulative thrombotic event rate over 30 days was high (52.8\%) [4]. These patients should therefore be anticoagulated with an alternative drug. Furthermore, patients should be carefully assessed for lower limb DVT [30]. Anticoagulation should at least be continued until recovery of platelet counts to a stable plateau [32]. Farner et al presented data suggesting that HIT patients without thrombosis still require therapeutic anticoagulation [33].

- HIT with thrombosis: HIT patients with acute thrombosis require systemic anticoagulation. Whereas anticoagulation can probably be continued just until resolution of thrombocytopenia in a patient with isolated HIT, HIT-associated thrombosis requires longer-term anticoagulation (several months) in most patients. It is important to start coumarins only after therapeutic anticoagulation has been achieved with a compatible anticoagulant and a substantial platelet count recovery to a stable plateau has occurred to avoid coumarin induced venous limb gangrene [5]. This is an iatrogenic complication in which warfarin therapy leads to microvascular thrombosis, and limb loss, by causing acute depletion of a Vitamin K-dependent natural anticoagulant (protein $\mathrm{C}$ ), while at the same time failing to down-regulate the increased thrombin generation caused by acute HIT.

Diagnosis and Treatment of Heparin-Induced

Thrombocytopenia
In case of strong clinical suspicion of HIT, patients should immediately be treated with an alternative anticoagulant. Awaiting laboratory confirmation would cause a significant delay in most cases, enhancing the risk for the patient substantially.

\section{Alternative Anticoagulants in HIT}

\section{Danaparoid}

The heparinoid danaparoid-sodium [34] mainly exhibits anti-Xa activity, with a half life of approx 24 hours. Its antithrombin activity has a half-life of about 2-4 hours. As danaparoid is mainly eliminated renally, dose reduction of about $30 \%$ is required to maintain aFXa levels within the therapeutic range in patients with renal failure [34].

Bioavailability is nearly $100 \%$ after s.c. injection and plasma levels are usually predictable. Monitoring is recommended in substantial renal impairment, unusually high or low body weight, life- or limb threatening thrombosis, unexpected bleeding and critically ill or unstable patients [34]. Danaparoid does not significantly prolong aPTT, activated clotting time or INR, thus measurement of anti-FXaactivity for monitoring using a calibration curve with danaparoid is required.

Danaparoid has been assessed in one compassionate use program and in one small prospective, randomized clinical trial [34]. In the named patient program, 667 HIT patients with 708 treatment episodes were included. The treating physicians judged treatment to be successful in $93 \%$ because of platelet count recovery or clinical improvement of patients. In $1.7 \%$ of patients new thromboembolic complication occurred. Of 114 (17.1\%) deaths, 14 (12.2\%) were thought to be related to the danaparoid treatment.

Danaparoid cross-reacts with HIT-antibodies in-vitro at a rate of $7-50 \%$ depending on the sensitivity of the assay used [34]. Despite anecdotal reports of unfavorable outcomes, two studies found no difference in clinical outcomes comparing HIT patients treated with danaparoid with or without in-vitro cross-reactivity [35]. It therefore seems reasonable to limit testing for in-vitro cross-reactions to patients who develop new, progressive or recurrent thrombocytopenia or thrombosis during treatment with danaparoid [34]. In case of a positive result in such a patient, anticoagulation should be switched to a different drug.

\section{Hirudin}

Hirudin is a recombinant direct thrombin inhibitor. Lepirudin is the most extensively investigated drug in HIT [36].Terminal plasma elimination half-lifes (t1/2ß) are 0.8 1.7 hours after intravenous (i.v.) injection of bolus lepirudin doses of $0.01-0.5 \mathrm{mg} / \mathrm{kg}$, and $1.1-2.0$ hours after continuous i.v. infusions over 6 hours.

Pathophysiol Haemost Thromb 2003/2004;33:407-412 
Renal clearance accounts for approximately $90 \%$ of the systemic clearance. The $t 1 / 2 \beta$ of lepirudin is lengthened with deterioration of renal function [37]; in nephrectomized humans it is prolonged to up to 150 hours.

For monitoring, the aPTT shows considerable variability between patients. At higher hirudin plasma levels (aPTT values $>70$ seconds), the concentration-aPTT curve flattens and the correlation becomes poor. The ecarin clotting time (ECT) should be used in patients requiring high hirudin doses, for example during cardio-pulmonary bypass [38]. There is no antidote available for hirudin.

Two prospective, multicenter, historically-controlled trials, HAT-1 $(n=82)$ and HAT-2 $(n=112)$ were conducted in patients with the clinical diagnosis of HIT confirmed by laboratory tests [36].

Both studies had similar mortality rates $(7.3 \%$ and 9.8\%); however, limb amputations (3.7\% and 8.9\%) and new thromboembolic complications (9.8\% and $17.9 \%)$ differed between the studies.

The combined endpoint (new TECs, limb amputation, death) at day 35 was $52.1 \%$ in a historical control $(n=120)$ and $25.4 \%$ in the HAT-1- $(\mathrm{P}=0.014$; adjusted risk ratio 0.508; 95\% CI, 0.290-0.892) and 30.9\% in the HAT-2 study ( $\mathrm{P}=0.15$; adjusted risk ratio 0.709; 95\% CI, 0.44-1.14).

In both studies more bleeding events occurred in the lepirudin-treated group as compared to controls (39.1\% [HAT1], 44.6\% [HAT-2] vs. 27.2\%), but not more bleeding events requiring transfusion (9.9\% [HAT-1], 12.9\% [HAT-2] vs 9.1\%).

In a meta-analysis of both studies, patients with HIT and ongoing thrombosis treated with lepirudin showed a clear reduction of the combined endpoint compared to the historical control group $(\mathrm{P}=0.004)$ [23]. An aPTT ratio of 1.5 to 2.5 is the recommended target range [23].

Patients with acute HIT (N=91) were also shown to benefit from lepirudin treatment in a study using a contemporaneous control group ( $\mathrm{N}=47)$ : new TECS $4.4 \%$ vs. $14.0 \%$, $\mathrm{P}=0.02$; combined end-point $19.8 \%$ vs. $29.8 \%, \mathrm{P}=0.0281$ [55].

Whereas a change in the prothrombin time observed at the start of treatment with lepirudin is of minor clinical relevance, no evidence was found indicating that cessation of lepirudin causes a change of the INRs [23].

Hirudin can induce anti-hirudin antibodies [39,40]. Of 198 HIT patients treated for 5 days with lepirudin, 45\% developed anti-hirudin antibodies of the immunoglobulin G (IgG) class [39].

In $2-3 \%$ of patients with anti-hirudin antibodies, the hirudin dose had to be decreased by more than $60 \%$ to maintain the aPTT within the target range. [39] This enhanced anticoagulant effect may be caused by decreased renal elimination of the hirudin-anti-hirudin complexes. In a few patients, development of anti-hirudin antibodies was paralelled by a decrease of the aPTT.

Nine anaphylactic reactions to lepirudin have been reported in $\sim 35,000$ treatments, 4 of them fatal. Five of these reactions occurred during reexposure (at a reexposure rate of $\sim 7.5 \%$ ) [41]. Consequently, lepirudin should be started in a setting with access to treatment of anaphylaxis, and the bolus should be omitted unless there is life- or limbthreatening thrombosis [41].

\section{Argatroban}

Argatroban (MW 526.66 Da) is a synthetic direct thrombin inhibitor. It distributes mainly in the extracellular fluid (distribution volume $174 \mathrm{~mL} / \mathrm{kg}$ ), and is $54 \%$ serum proteinbound. Its elimination half-life is 39-51 minutes [42]. The main route of metabolism is the liver. Steady state levels are reached within 1-3 hours.

Argatroban is routinely monitored by the aPTT. It also increases the ACT, INR, thrombin time, and ecarin clotting time. As argatroban prolonges the INR, during change from argatroban to oral anticoagulation special precautions have to be followed [43].

There is no specific antidote available for argatroban. Across 3 studies [43-45], 754 patients, with the clinical diagnosis of HIT, received argatroban therapy [ $2 \mu \mathrm{g} / \mathrm{kg} / \mathrm{min}$ i.v. (up to $10 \mathrm{~g} / \mathrm{kg} / \mathrm{min}$, max) aPTT adjusted].

In the first study ARG-911, 304 patients having HIT $(n=160)$ or HIT with thrombosis $(n=144)$ received argatroban. Compared to 193 historical controls (HIT, $n=147$; HIT with thrombosis, $n=46$ ) the composite endpoint was reduced in argatroban-treated patients by time-to-event analysis in HIT (hazard ratio=0.60; 95\% CI, 0.40-0.89, $\mathrm{P}=0.010$ ) and HIT with thrombosis (hazard ratio=0.57; 95\% CI, 0.36-0.90, $\mathrm{P}=0.014$ ).

In the other 2 studies, argatroban treatment was also favored, compared with controls, by time-to-event analysis [43]. The overall major bleeding rate was $6.6 \%$ for argatroban-treated patients and $6.7 \%$ for the historical control.

\section{Fondaparinux and HIT}

HIT-antibody seroconversion occurred in patients treated with fondaparinux following knee- and hip-replacement ( $\mathrm{n}=364$ and 989 respectively), at a rate similar to patients treated with LMWH. However, no thrombocytopenia indicating clinical HIT was observed in this study in fondaparinux treated patients [46]. Furthermore, HIT-sera of 39 patients did not cause platelet activation with fondaparinux in various functional assays, indicating absence of crossreactivity [47]. Successful treatment of 5 HIT-patients with fondaparinux was reported recently [48], but systematic data on treatment of HIT-patients with fondaparinux are lacking. 


\section{Reexposure of Patients with a History of HIT to Heparin}

Short term reexposure to heparin in patients with a history of HIT may be considered in special clinical settings as only patients who had received heparin within the past 100 days seem to develop early onset of HIT ( $<5$ days) [2]. This temporal pattern offers treatment options in patients with a history of HIT who are in need of surgery necessitating cardiopulmonary bypass. Provided no circulating HITantibodies are detectable, these patients can receive heparin during CPB if heparin exposure is strictly avoided pre- and postoperatively. With this strategy, complications during CPB with anticoagulants for which no antidote is available, i.e. hirudin, argatroban or danaparoid, can be avoided $[38,49,50]$.

\section{Children}

Schiffmann et al. [51] described a 12-year-old patient with HIT and multiple TECs. Using a bolus of $0.2 \mathrm{mg} / \mathrm{kg}$ lepirudin followed by a continuous infusion of 0.1-0.7 $\mathrm{mg} / \mathrm{kg} / \mathrm{h}$, the aPTT was prolonged to $45-85$ sec. Planned surgical interventions were possible after discontinuing lepirudin for 4 hours.

Danaparoid has been used in children successfully [52]. For thrombosis prophylaxis in children below $55 \mathrm{~kg}$, the manufacturer [53] recommends subcutaneous injections of $10 \mathrm{aFXaU} / \mathrm{kg}$ bid, in acute thrombosis a bolus of 30 $\mathrm{aFXaU} / \mathrm{kg}$ followed by $1.2-2.0 \mathrm{aFXaU} / \mathrm{kg} / \mathrm{h}$ with a target range of $0.4-0.6 \mathrm{aFXaU} / \mathrm{mL}$ or $0.5-0.8 \mathrm{aFXaU} / \mathrm{mL}$ respectively.

Klenner et al (2004) recently showed that newborns and infants $<4$ years undergoing cardiac surgery (incidence $\sim 1$ $2 \%$ ), and adolescents receiving heparin for treatment of thrombosis are the two main risk groups for HIT in children and that the 'adult cut-off' in antigen assays is probably appropriate for children [54].

\section{References}

1 Warkentin TE, Roberts RS., Hirsh J, Kelton JG. An improved definition of immune heparin-induced thrombocytopenia in postoperative orthopedic patients. Arch Intern Med 2003;163:2518-2524.

$\checkmark 2$ Warkentin TE, Kelton JG. Temporal aspects of heparin-induced thrombocytopenia. N Enlg J Med 2001:344:1286-1292.

3 Warkentin TE. Clinical picture of heparin-induced thrombocytopenia. in: Warkentin TE and Greinacher A. eds. Heparin-induced thrombocytopenia, Marcel Dekker, New York 3rd ed., 2004:53-106.

4 WarkentinTE, Kelton JE. A 14-year study of heparin-induced thrombocytopenia. Am J Med 1996; 101: 502-507.

5 Warkentin TE, Elavathil LJ, Hayward CPM, Johnston MA, Russett JI, Kelton JG. The pathogenesis of venous limb gangrene associated with heparin-induced thrombocytopenia. Ann Intern Med 1997;127:804-812.

6 Pohl C, Klockgether T, Greinacher A, Hanfland P, Harbrecht U. Neurological complications in heparin-induced thrombocytopenia. Lancet 1999;353:1678-1679.

7 Warkentin TE, Sikov WM, Lillicrap DP. Multicentric warfarin-induced skin necrosis complicating heparin-induced thrombocytopenia. Am J Hematol 1999;62:44-48.

$>8$ Warkentin TE, Levine MN, Hirsh J, Horsewood P, Roberts RS, Gent M, Kelton JG. Heparin-induced thrombocytopenia in patients treated with lowmolecular-weight heparin or unfractionated heparin. N Engl J Med 1995;332:1330-1335.
Amiral J, Peynaud-Debayle E, Wolf M, Bridey F, Vissac A-M, Meyer D. Generation of antibodies to heparin-PF4 complexes without thrombocytopenia in patients treated with unfractionated or lowmolecular-weight heparin. Am J Hematol 1996; 52:90-95.

10 Visentin GP, Malik M, Cyganiak KA, Aster RH. Patients treated with unfractionated heparin during open heart surgery are at high risk to form antibodies reactive with heparin:platelet factor 4 complexes. J Lab Clin Med 1996;128:376-383.

11 Bauer TL, Arepally G, Konkle BA, Mestichelli B, Shapiro SS, Cines DB, Poncz M, McNulty S, Amiral J, Hauck WW, Edie RN, Mannion JC. Prevalence of heparin-associated antibodies without thrombosis in patients undergoing cardiopulmonary bypass surgery Circulation 1997:95:1242-1246.

12 Trossaert M, Gaillard A, Cyganiak KA, Aster RH High incidence of anti-heparin/platelet factor 4 antibodies after cardiopulmonary bypass. $\mathrm{Br} \mathrm{J}$ Haematol 1998;101:653-655.

13 Pouplard C, May MA, Iochmann S, Amiral J, Vissac AM, Marchand M, Gruel Y. Antibodies to platelet factor 4-heparin after cardiopulmonary bypass in patients anticoagulated with unfractionated heparin or a low-molecular-weight heparin: clinical implications for heparin-induced thrombocytopenia. Circulation 1999;99:2530-2536.

14 Lee DH, Warkentin TE. Frequency of heparininduced thrombocytopenia. in: Warkentin TE and Greinacher A. eds. Heparin-induced thrombocytopenia, Marcel Dekker, New York 3rd ed., 2004:107-148.
15 Greinacher A, Poetzsch B, Amiral J, Dummel V, Eichner A, Mueller-Eckhardt. Heparin-associated thrombocytopenia:isolation of the antibody and characterization of a multimolecular PF4-heparin complex as the major antigen. Thromb Haemost 1994;71: 247-251.

16 Amiral J, Meyer D. Heparin-dependent antigens in heparin-induced antibodies. in: Warkentin TE and Greinacher A. eds. Heparin-induced thrombocytopenia, Marcel Dekker, New York, 3rd ed., 2004:165-177.

17 Visentin GP, Lin CY, Aster RH. Molecular immunopathogenesis of heparin-induced thrombocytopenia. in: Warkentin TE and Greinacher A. eds. Heparin-induced thrombocytopenia, Marcel Dekker, New York 3rd ed., 2004:179-196.

18 Greinacher A, Alban S, Dummel V, Franz G Mueller-Eckhardt C. Characterization of the structural requirements for a carbohydrate based anticoagulant with a reduced risk of inducing the immunological type of heparin-associated thrombocytopenia. Thromb Haemost 1995;74:886-892.

19 Suh JS, Malik MI, Aster RH, Visentin GP. Characterization of the humoral immune response in heparin-induced thrombocytopenia. Am J Hematol 1997;54:196-201.

20 Amiral J, Wolf M, Fischer A, Boyer-Neumann C, Vissac A, Meyer D. Pathogenicity of IgA and/or IgM antibodies to heparin-PF4 complexes in patients with heparin-induced thrombocytopenia. Br J Haematol 1996;92:954-959.

21 Denomme GA. The platelet Fc receptor in heparin-induced thrombocytopenia. in: Warkentin $\mathrm{TE}$ and Greinacher A. eds. Heparin-induced thrombocytopenia, Marcel Dekker, New York 3rd ed., 2004:223-250. 
22 Warkentin TE, Chong BH, Greinacher A.Heparininduced thrombocytopenia: towards consensus. Thromb Haemost 1998;79:1-7.

23 Greinacher A, Eichler P, Lubenow N, Kwasny H, Luz M. Heparin-induced thrombocytopenia with thromboembolic complications: meta-analysis of two prospective trials to assess the value of parenteral treatment with lepirudin and its therapeutic aPTT range. Blood 2000;96:846-851.

24 Chong BH, Murray B, Berndt MC, Dunlop LC, Brighton T, Chesterman CN. Plasma P-selectin is increased in thrombotic consumptive platelet disorders. Blood 1994;83:1535-1541.

25 Warkentin TE, Hayward CP, Boshkov LK, Santos AV, Sheppard JA, Bode AP, Kelton JG. Sera from patients with heparin-induced thrombocytopenia generate platelet-derived microparticles with procoagulant activity: An explanation for the thrombotic complications of heparin-induced thrombocytopenia. Blood 1994;84:3691-3699.

26 Cines DB, Tomaski A, Tannenbaum S. Immune endothelial-cell injury in heparin-associated thrombocytopenia. N Engl J Med 1987;316:581589.

27 Pouplard C, Iochmann S, Renard B, Herault O, Colombat P, Amiral J, Gruel Y.Induction of monocyte tissue factor expression by antibodies to heparin-platelet factor 4 complexes developed in heparin-induced thrombocytopenia. Blood 2001;97:3300-3302.

28 Warkentin TE and Greinacher A. Laboratory testing for heparin-induced thrombocytopenia.in: Warkentin TE and Greinacher A. eds. Heparininduced thrombocytopenia, Marcel Dekker, New York 3rd ed., 2004:271-311.

29 Eichler P, Raschke R, Lubenow N, Meyer O Schwind P, Greinacher A. The new ID heparin/PF4 antibody test for rapid detection of heparin-induced antibodies in comparison with functional and antigenic assays. Br J Haematol 2002;116:887-91.

30 Wallis DE, Workman DL, Lewis BE, Steen L, Pifarre R, Moran JF. Failure of early heparin cessation as treatment for heparin-induced thrombocytopenia. Am J Med 1999;106:629-635.

31 Ganzer D, Gutezeit A, Mayer G. [Potentials risks in drug prevention of thrombosis--low-molecularweight heparin versus standard heparin]. Z Orthop Ihre Grenzgeb 1999;137:457-461.

32 Greinacher A, Warkentin TE. Treatment of heparin-induced thrombocytopenia: an overview. in: Warkentin TE and Greinacher A. eds. Heparininduced thrombocytopenia, Marcel Dekker, 3rd ed., 2004:335-370.

33 Farner B, Eichler P, Kroll H, Greinacher A. A comparison of danaparoid and lepirudin in heparininduced thrombocytopenia. Thromb Haemost 2001;85:950-957.
34 Chong BH, Magnani HN. Danaparoid for the treatment of heparin-induced thrombocytopenia. in: Warkentin TE and Greinacher A. eds. Heparininduced thrombocytopenia, Marcel Dekker, New York, 3rd ed., 2004:371-396.

35 Warkentin TE. Danaparoid (Orgaran ) for the treatment of heparin-induced thrombocytopenia (HIT) and thrombosis: effects on in vivo thrombin and cross-linked fibrin generation, and evaluation of the clinical significance of in vitro cross-reactivity of danaparoid for HIT-IgG. Blood 1996;88:626a.

36 Lubenow N, Greinacher A. Heparin-induced thrombocytopenia. Recommendations for optimal use of recombinant hirudin. BioDrugs 2000;14:109-125.

37 Vanholder R, Camez A, Veys N, Van Loo A Dhondt A, Ringoir S. Pharmacokinetics of recombinant hirudin in hemodialyzed end-stage renal failure patients. Thromb Haemost 1997;77:650655.

38 Pötzsch B, Madlener K. Management of cardiopulmonary bypass anticoagulation in patients with heparin-induced thrombocytopenia. in: Warkentin TE and Greinacher A. eds. Heparininduced thrombocytopenia, Marcel Dekker, New York, 3rd ed., 2004:531-551.

39 Eichler P, Friesen HJ, Lubenow N, Jaeger B, Greinacher A. Antihirudin antibodies in patients with heparin-induced thrombocytopenia treated with lepirudin: incidence, effects on aPTT, and clinical relevance. Blood 2000;96:2373-2378.

40 Huhle, G, Hoffmann U, Song X, Wang LC, Heene DL, Harenberg J. Immunologic response to recombinant hirudin in HIT type II patients during long-term treatment. $\mathrm{Br} \mathrm{J}$ Haematol 1999;106:195-201.

41 Greinacher A, Lubenow N, Eichler P. Anaphylactic and anaphylactoid reactios associated with lepirudin in patients with heparin-induced thrombocytopenia. Circulation 2003;108:20622065.

42 Swan SK, Hursting MJ. The pharmacokinetics and pharmacodynamics of argatroban: effects of age, gender, and hepatic or renal dysfunction. Pharmacotherapy 2000;20:318-329.

43 Lewis BE, Hursting MJ. Argatroban Therapy in Heparin-Induced Thrombo-cytopenia. in: Warkentin TE and Greinacher A. eds. Heparininduced thrombocytopenia, Marcel Dekker, 3rd ed., 2004;437-474.

44 Lewis BE; Wallis DE, Berkowitz SD, Matthai WH, Fareed J, Walenga JM, Bartholomew J, Sham R, Lerner RG, Zeigler ZR, Rustagi PK, Jang I-K, Rifkin SD, Moran J, Hursting MJ, Kelton JG for the ARG-911 Study Investigators. Argatroban anticoagulant therapy in patients with heparininduced thrombocytopenia. Circulation 2001;103:1838-1843.
45 Lewis BE, Wallis DE, Leya F, Hursting MJ, Kelton JG; Argatroban-915 Investigators. Argatroban anticoagulation in patients with heparin-induced thrombocytopenia. Arch Intern Med 2003;163:1849-1856.

46 Warkentin TE, Cook RJ, Marder VJ, Kelton JG. Comparison of heparin-induced thrombocytopenia antibody (HIT-Ab) generation and in vitro crossreactivity after elective hip or knee replacement surgery in patients receiving antithrombotic prophylaxis with fondaparinux or enoxaparin. Blood 2003; 102:164a

47 Savi P, Chong B, Greinacher A, Gruel Y, Kelton J, Petitou M, Herault J-P, Warkentin T, Meulemann D, Cariou R, Herbert J-M. Effect of fondaparinux on platelet activation in the presence of heparindependent anti-platelet antibodies. A blinded comparative multicenter study with unfractionated heparin. Blood 2003;102: 319a

48 Kuo KHM, Kovacs MJ. Successful treatment of heparin induced thrombocytopenia with fondaparinux. Blood 2003;102:319a

49 Pötzsch B, Klovekorn WP, Madlener K. Use of heparin during cardiopulmonary bypass in patients with a history of heparin-induced thrombocytopenia. N Engl J Med 2000;343:515.

50 Selleng S, Lubenow N, Wollert H-G, Müllejans B, Greinacher A. Emergency cardiopulmonary bypass in a bilaterally nephrectomized patient with a history of heparin-induced thrombocytopenia: successful reexposure to heparin. Ann Thorac Surg 2000;71:1041-1042

51 Schiffmann H, Unterhalt M, Harms K, Figulla HR, Völpel H, Greinacher A. Successful treatment of heparin-induced thrombocytopenia (HIT) type II in childhood with recombinant hirudin. Monatsschr Kinderheilkd 1997;145:606-612.

52 Ranze O, Ranze P, Magnani HN, Greinacher A. Heparin-induced thrombocytopenia in paediatric patients - a review of the literature and a new case treated with danaparoid sodium. Eur J Pediatr 1999;158 (Suppl3):S130-S133.

53 Akzo-Organon, Oss, Netherlands, Danaparoid Product Information, 1999.

54 Klenner AF, Lubenow N, Raschke R, Greinacher A. Heparin-induced thrombocytopenia in children: 12 new cases and review of the literature. Thromb Haemost 2004;91:719-724.

55 Lubenow N, Eichler P, Lietz T, Farner B, Greinalher A. Lepirudin for the prophylaxis of thrombosis in patients with acute isolated heparininduced thrombocytopenia: an analysis of 3 prospective studies. Blood 2004;104:3072-3077.

56 Greinalher A, Lubenow N. Heparin-induced thrombocytopenia. Biomedical Progress 202;42:44-45. 